DOI: 10.14526/2070-4798-2020-15-1-158-164

\title{
The effect of the combined aerobic and power training in the patients with chronic heart disease
}

\author{
Nadezhda V. Shuvalova, Gerold L. Drandrov*, Svetlana V. Lezhenina, Antonina V. \\ Karpunina, Venera P. Akimova, Elena A. Denisova, Lyudmila Yu. Kupriyanova \\ I.Ya. Yaskovlev State Pedagogical University, Cheboksary, Russia \\ ORCID: oooo-0002-5128-626X, msta77@yandex.ru \\ ORCID: oOOO-OOO2-2214-270X, gerold49@mail.ru* \\ ORCID: oooo-0oo2-9449-8o86,svl-8@bk.ru \\ ORCID: oOoo-Ooo2-1156-2303, ctschgu@gmail.com \\ ORCID: OOOO-Ooo1-7167-4510, Akimova.venera@gmail.com \\ ORCID: OOOO-Ooo2-5054-3826,gubanova.elena@gmail.com \\ ORCID: oOoo-OoO2-2629-518o, ldmlkuprianova@gmail.com
}

\begin{abstract}
Cardiovascular rehabilitation is generally adopted component of a complex treatment for patients with cardiovascular diseases. It improves physical fitness, improves the quality of life and decreases death rate from cardiovascular diseases. Materials. The effectiveness of combined trainings (aerobic and power) estimation according to the indices of physical readiness and muscle power among the patients with chronic heart disease (CHD). In general 32 patients were examined before and after 12 weeks of aerobics lessons together with 3 weeks of power training (with weight) ( 3 times a week). One training lesson lasted 60 minutes (10 minutes of warming-up phase, 25 minutes of aerobic load at ergometer, 15 minutes of training). Research methods. Information sources analysis and summarizing, testing, rehabilitation training, monitoring, methods of mathematical statistics. Results. The results of our research showed that 12 weeks of cardiovascular rehabilitation combined training provided statistically valid increase of throughflow capacity of oxygen-transportation system, physical working capacity increase, skeletal muscles strength and the quality of life improvement in the patients with chronic heart disease. Conclusion. We can suppose that a positive effect from such training lessons can be only in case if the patient regularly fulfills power and aerobic exercises. If regular exercises don't correspond with created by us program of cardiovascular rehabilitation, the values of aerobic capacity and physical working capacity, muscle power return to the initial level.
\end{abstract}

Keywords: chronic heart disease (CHD), cardiovascular rehabilitation, aerobic and power trainings, ergometer, power training with weight lifting, relaxation phase.

For citation: Nadezhda V. Shuvalova, Gerold L. Drandrov*, Svetlana V. Lezhenina, Antonina V. Karpunina, Venera P. Akimova, Elena A. Denisova, Lyudmila Yu. Kupriyanova. The effect of the combined aerobic and power training in the patients with chronic heart disease. Russian Journal of Physical Education and Sport. 2020; 15(1): 127-131. DOI: 10.14526/2070-4798-2020-15-1-158-164

\section{INTRODUCTION}

Cardiovascular rehabilitation is generally adopted component of a complex treatment for patients with cardiovascular diseases [13].It improves physical fitness, improves the quality of life [14] and decreases death rate from cardiovascular diseases. Dynamic exercises, directed toward aerobic endurance (walking, riding a bicycle, recreational running, swimming and others) form the base of cardiovascular system rehabilitation program [5;6;7;11].If we speak about cardiovascular safety of power training (the trainings with weight use), as it was underlined in some research works
$[4,13,8,15,16]$, they are safe part of cardiovascular rehabilitation.

The aim of the research work is to create and test an effective program of cardiovascular rehabilitation in men with chronic heart disease using aerobic and power exercises.

\section{RESEARCH METHODS}

32 men at the age of $63,0 \pm 10$ years with CHD were examined. The indices of the left ventricular ejection fraction (LVEF) among them were in the average $42 \pm 8 \%$. All patients went through coronary angiography. They took part in 
the experiment (12-weeks) connected with studying the effectiveness of created by us cardiovascular rehabilitation program. During the experiment the patients didn't take pharmacological treatment with beta-adrenergic blocking agents, ACE inhibitors and statins. All patients went through the course of rehabilitation training and finished successfully the whole rehabilitation program. The research was approved by local Ethical Committee. All patients gave written informed consent.

Before and after the rehabilitation training patients had ECG monitoring at rest, in a lying position and on back with further three minutes adaptation of sitting at ergometer. The load increased each 2 minutes for $20 \mathrm{~W}$ till the symptoms of the restricted (limited) maximum. They were revealed using spiroergometry.

The anaerobic threshold was determined according to the changes of ventilation-respiratory parameters. Physical load, heart rate and RPE values for the training lessons corresponded with anaerobic threshold (AnT). Before the beginning of the training with the weight (the third week of rehabilitation training) with the patients we organized isometric test, in order to define the influence of isometric load on the level of blood pressure. In case of normal value of blood pressure the test was fulfilled - a single maximum (1-RM) for all exercises with the weight. The test was repeated on the $6^{\text {th }}$ and the $12^{\text {th }}$ weeks of the rehabilitation training program.

The rehabilitation training program was realized during 12 weeks. The training lessons lasted 60 minutes and were held 3 times a week.

During the first and the second weeks the training lessons of aerobic orientation were held. They included warming-up (10 min.), aerobic exercises (40 min.) and relaxation exercises (10 $\min$.).

During further 10 weeks combined lessons were held. They included warming-up (10 min.), aerobic (25 min.) and power (15 min.) physical exercises and relaxation exercises (10 min.).

The aim of warming-up was to prepare cardiovascular-system and locomotor apparatus to the training load and prevent osteoarticular and muscle systems injuries. Warming-up included the complex of exercises for dynamic endurance (generally developing exercises and gymnastic exercises at special training simulators) and flexibility development (stretching exercises).

Aerobic phase of the training lessons was held at a bicycle ergometer (Ergoline REHA E90o), controlled by ErgoSoft + for Windows program. The intensity of aerobic trainings was defined at the level of anaerobic threshold (AnT).

Power oriented part of the trainings was held using multifunctional power training simulators TK-HC COMPACT. The patients fulfilled four power oriented exercises from lying and sitting positions: bench press, sitting chin-up, legs extension and bending.

The intensity of the fulfilled exercises was estimated with the help of methodical technique of 1-RM value measurement; the training load was calculated in percentage of maximum: $30-60 \%$ for $1-\mathrm{RM}$, and every week there was $10 \%$ increase. In terms of one training lesson each exercise was fulfilled in three series with 5 repetitions. Before the power oriented trainings all patients studied the demands claimed on correct correspondence between respiration and the phases of power oriented exercises fulfillment.

Heart rate, blood pressure indices, ECG were controlled during the whole training. ECG was stated both during aerobic phase and 1-RM test.

\section{RESULTS AND DISCUSSION}

Rehabilitation program led to statistically valid throughflow capacity increase of oxygentransfer systems, physical working capacity increase, muscle power increase (table 1 ).

Isometric stress-test use during diagnostics among the patients with heart diseases was earlier considered not reasonable. Nevertheless, the elements of isometric muscle tension are the part of everyday activity even among this kind of patients.

Static power oriented loads very often lead to blood pressure increase in comparison with aerobic training. It can cause after effects, including ischemia, serious rhythm violations and unfavorable influences on left ventricle remodeling after acute myocardial infarction. 
Table 1-Aerobic load indices, working characteristics and maximum load in 1-RM test before and after the rehabilitation training

$\begin{array}{cccc}\begin{array}{c}\text { Parameters of physical working capacity and } \\ \text { power qualities }\end{array} & \text { Before the training } & \text { After the training } & \text { P } \\ \text { VO2sl }[\mathrm{ml} / \mathrm{min}] & 1536 \pm 245 & 1768 \pm 421 & <0,01 \\ \text { VO2sl } / \mathrm{kg}[\mathrm{ml} / \mathrm{min}] & 17,4 \pm 2,8 & 20,9 \pm 4,7 & <0,01 \\ \text { Wsl[W] } & 95,0 \pm 19,0 & 120,0 \pm 33,0 & <0,01 \\ \text { Wsl } / \mathrm{kg}[\mathrm{W} / \mathrm{kg}] & 1,0 \pm 0,21 & 1,3 \pm 0,37 & <0,01 \\ \text { Bench press[kg] } & 35,0 \pm 9,0 & 42,0 \pm 8,0 & <0,01 \\ \text { Sitting chin-up[kg] } & 36,0 \pm 8,0 & 44,0 \pm 6,0 & <0,01 \\ \text { Knee joint extension }[\mathrm{kg}] & 33,0 \pm 8,0 & 42,0 \pm 8,0 & <0,01\end{array}$

Notes: VO2sl - symptoms of the limited oxygen consumption, Wsl - symptoms of limited productivity, $\mathrm{p}$ - statistical significance

Earlier held research works showed positive influence of static load on cardiovascular system functional abilities development. Since 1990-s training with weigh (or power oriented training) was the part of rehabilitation traditional programs among patients with heart diseases. This form of training has less ischemic aftereffects, than aerobic trainings (including stress-tests).

As a possible reason for this is considered a low frequency of heart rate, which together with diastolic pressure leads to myocardial perfusion improvement.

An important role of power oriented trainings is muscle power increase. It leads to working capacity and endurance increase in terms of sub-maximum loads. We also have the results. They prove positive influence of the trainings with weight on tolerance to glucose and sensitivity to insulin.

The results of our research also prove positive influence of power oriented exercises together with aerobic exercises on health and functional state of patients with CHD.

Sporoergometric study, held in terms of created by us program of cardiovascular rehabilitation, is a necessary and important diagnostic event: the received during the test results show the amount of used by organism oxygen and have high predicting power for the patients with
CHD and cardiac decompensation [10].

In the end of 1980-s K. Weber offered his own classification for the degree of functional state estimation in the patients with CHD depending on peak oxygen consumption indices (table 2) [16]. For decades this classification was the only one classification, based on peak oxygen consumption indices, for the patients' state determination and to decide whether heart transplantation is necessary or not $[1 ; 2 ; 3]$. Later this classification was added, however, it was based on the indices offered by $K$. Weber [3].

Maximum aerobic load indices less than 10 $\mathrm{ml}$ prove hard heart injury with unfavorable results. Patients with oxygen consumption more than 20 $\mathrm{ml}$ belong to the group of people with low or zero functional disability.

Some research works prove positive influence of power oriented load safety for the patients with left ventricle disorder [12;7]. The authors of these research works didn't reveal any complications during power oriented exercises fulfillment.

None of our patients had clinical indices characteristics of ischemia. The results of a continuous monitoring also didn't reveal serious heart rate violations during cardiovascular rehabilitation program realization. Training lessons 
with weight didn't have negative effects and the patients were tolerant.

We can suppose that the training lessons with weight of low and moderate intensity are safe and provide power increase of great muscles groups. Power oriented exercises fulfillment leads to symptoms of limited oxygen consumption increase.

After 12 weeks of cardiovascular rehabilitation we revealed not only considerable muscles power increase. Owing to the combination of aerobic and power exercises aerobic working capacity and patients' tolerance to physical load also increased.

Thus, power oriented exercises combination with aerobic load at the level of anaerobic threshold in terms of combined training lessons is safe and physiologically effective for the patients with cardiac decompensation with the indices of oxygen consumption during the peak of the limited maximal symptoms more than $20 \mathrm{ml}$.

Table 2 - Cardiac decompensation classification according to K. Weber [3]

\begin{tabular}{|c|c|c|c|}
\hline Class & Peak, $\mathrm{ml} / \mathrm{kg} / \mathrm{min}$ & Anaerobic threshold, $\mathrm{mlO} 2 / \mathrm{kg} / \mathrm{min}$ & Functional status \\
\hline $\mathrm{A}$ & $>20$ & $>14$ & Good \\
\hline $\mathrm{B}$ & $16-20$ & $11-14$ & Satisfactory \\
\hline $\mathrm{C}$ & $10-15$ & $8-11$ & Moderate injury \\
\hline $\mathrm{D}$ & $<10$ & $<8$ & Hard injury \\
\hline
\end{tabular}

\section{CONCLUSION}

1. The results of our research showed that 12 weeks of the combined training program of cardiovascular rehabilitation provided statistically valid through flow capacity increase of oxygentransfer systems, working capacity increase, skeletal muscles strength and quality of life improvement in the patients with CHD.

2. We can suppose that a positive effect from such trainings preserves only if a patient continues going in for regular power oriented and aerobic exercises. If regular exercises don't correspond with the created by us program of cardiovascular rehabilitation, the values of aerobic capacity and physical working capacity, muscle power become initial, as they were before the trainings.

\section{REFERENCES}

1. Bokeriya L.A., Shatalov K.V., Koloskova N.N. Defining peak oxygen consumption among the patients with chronic heart disease. Klinicheskaya fiziologiya krovoobracheniya. 2011; 4: 5-8 [In Russ.].

2. Koloskova N.N., Shatalov K.V., Bokeriya L.A. Peak oxygen consumption determination: physiological basis and application spheres. Kreativnaya kardiologiya. 2014; 1: 48-57 [In Russ.].

3. Atkins JM, Matthews OA, Blomqvist CG, Mullins CB. Incidence of arrhytmias induced by isometric and dynamic exercise. Br Heart J. 1976; 38: $465-471$.

4. Balady GJ, Fletcher BJ, Froelicher ES, et al. Cardiac rehabilitation programs. A statement for health-care professionals from the American Heart Association. Circulation. 1994; 90(3): 16021610.

5. Bjarnason-Wehrens B, Mayer-Berger W, Meister ER, Baum K, Hambrecht R, Gielen S. Recommen- dations for resistance exercise in cardiac rehabilitation. Recommendations of the German federation for cardiovascular prevention and rehabilitation. Euro J CardiovascPrevRehabil. 2004; 11: 352-361.

6. Cheetham G, Green D, Collis J, et al. Effect of aerobic and resistance exercise on central hemodynamic responses in severe chronic heart failure. J ApplPhysiol. 2002; 93: 175-180.

7. Chludilová V, Jančík J, Mífková L, et al. Dvanáctitýdenní rehabilitační program u nemocných s ICHS: kombinaceaerobního a silovéhotréninku. In: Optimální působení tělesné zátěže a výživy, Hradec Králové: UHK. 2005: 197201.

8. Clausen JP. Circulatory adjustments to dynamic exercise and effect of physical training in normal subjects and in patients with coronary artery disease. Prog Cardiovasc Dis. 1976; 18: 456-495.

9. Cohn JN, Rector TS. Prognosis of congestive heart failure and predictor of mortality. Am J Cardiol. 1988; 62: 1636-1641.

10. Fletcher GF, Balady GJ, Amsterdam EA, et al. Exercise standards for testing and training. A statement for healthcare professionals from the American Heart Association. Circulation. 2001; 104: 1694-1740.

11. Green DJ, Watts K, Maiorana AJ, et al. A comparison of ambulatory oxygen consumption during circuit training and aerobic exercise in patients with chronic heart failure. $J$ 
CardiopulmRehabil. 2001; 21: 167-174.

12. Chaloupka V, Siegelová J, Špinarová L, Skalická H, Karel I, Leisser J. Rehabilitace u nemocných s kardiovaskulárnímonemocněním. Cor Vasa. 2006; 48: 127-145.

13. Izawa $\mathrm{K}$ Hirano $\mathrm{Y}$, Jamada $\mathrm{S}$, et al.Improvement in physiological outcomes and health-related duality of life following cardiac rehabilitation in patients with acute myocardial infarction. Circ J. 2004; 68: 315-320.

14. Jančík J, Dobšák $P$, Svačinová $\mathrm{H}$, et al. Srovnání účinkuaerobního a kombinovanéhotréninku $\mathrm{s}$ tréninkem $\mathrm{s}$ posilovacímiprvkynaukazatelefunkční zdatnosti u srdečníhoselhání. Cor Vasa. 2004; 4: 32.

15. Weber K., Kinasewitz G., Janicki J. Oxygen utilization and ventilation during exercise in patients with chronic congestive heart failure. Circulation. 1982; 65: 1213-1223.

16. Felder H., Bursch S., Rast T. Descriptive summary: the dynamometer to measure trunk muscle. Pedagogiko-psihologicheskie I medicobiologicheskie problemy fizicheskoj kul'tury I sporta $=$ Russian Journal of Physical Educaiton and Sport. 2019; 14(1): 4-17. DOI: 10.14526/20704798-2019-14-1-4-17 [In Russ., In Engl.].

\section{Submitted: 13.02.202O}

\section{Author's information:}

Nadezhda V. Shuvalova - Doctor of Medicine Sciences, Professor, I.Ya. Yaskovlev State Pedagogical University, Cheboksary, 428015, Russia, Cheboksary, Moskovskiy ave., House 15, e-mail: msta77@ yandex.ru

Gerold L. Drandrov - Doctor of Pedagogics, Professor, I.Ya. Yaskovlev State Pedagogical University, Cheboksary, 428015, Russia, Cheboksary, Moskovskiy ave., House 15, e-mail: gerold49@mail.ru*

Svetlana V. Lezhenina - Candidate of Medicine Sciences, Associate Professor, I.Ya. Yaskovlev State Pedagogical University, Cheboksary, 428015, Russia, Cheboksary, Moskovskiy ave., House 15, e-mail: svl-8@bk.ru

Antonina V. Karpunina - Candidate of Medicine Sciences, Associate Professor, I.Ya. Yaskovlev State Pedagogical University, Cheboksary, 428015, Russia, Cheboksary, Moskovskiy ave., House 15, e-mail: ctschgu@gmail.com

Venera P. Akimova - Candidate of Medicine Sciences, Associate Professor, I.Ya. Yaskovlev State Pedagogical University, Cheboksary, 428015, Russia, Cheboksary, Moskovskiy ave., House 15, e-mail: Akimova.venera@gmail.com

Elena A. Denisova - Candidate of Medicine Sciences, Associate Professor, I.Ya. Yaskovlev State Pedagogical University, Cheboksary, 428015, Russia, Cheboksary, Moskovskiy ave., House 15, e-mail: gubanova.elena@gmail.com

Lyudmila Yu. Kupriyanova - Assistant, I.Ya. Yaskovlev State Pedagogical University, Cheboksary, 428015, Russia, Cheboksary, Moskovskiy ave., House 15, e-mail: ldmlkuprianova@gmail.com 